\section{Economics of Using Soybean Oil to Reduce Peach Freeze Damage and Thin Fruit}

\author{
Robert Pendergrass, ${ }^{1}$ \\ Roland K. Roberts, ${ }^{1,2}$ \\ Dennis E. D eyton, ${ }^{3}$ and \\ Carl E. Sams ${ }^{3}$
}

AdDitional InDEX wORds. Production costs, risk analysis

Summary. U sing soybean oil to control insect pests, delay bloom, and thin fruit in peach [Prunuspersica (L.) Batsch] production could reduce yield losses and fruit thinning costs compared to the current practice of using petroleum oil spray to control insect pests alone. The higher annual cost of soybean oil spray compared to petroleum oil spray was more than offset by higher average annual revenue from increased peach yields and lower thinning costs. At one location, soybean oil to delay bloom and thin fruit unambiguously reduced production risk. At another location, both mean and variance of returns were higher, but a lower coefficient of variation suggested lower relative risk for the soybean oil spray alternative. $R$ isk resulting from the unanticipated influence of weather and mismanagement on the effectiveness of soybean oil spray were not considered in this

We thank the Tennessee Soybean Promotion Board, theU nited Soybean Board, and the T ennessee A griculture Experiment Station for providing financial support for this study. The authors appreciate the assistance of John Cummins and the early reviews of this manuscript by J im L arson and Kelly Tiller. M ention of a trademark, proprietary product, or vendor does not constitute a guarantee or warranty of the product and does not imply its approval to the exclusion of other products or vendors that also may be suitable. The cost of publishing this paper was defrayed in part by the payment of page charges. Under postal regulations, this paper therefore must be hereby marked advertise ment solely to indicate this fact.

${ }^{1}$ Department of Agricultural Economics and Rural Sociology, The U niversity of Tennessee, Knoxville, TN 37901-1071.

${ }^{2} \mathrm{~T}$ o whom correspondence should be sent.

${ }^{3} \mathrm{D}$ epartment of Plant and Soil Sciences, TheU niversity of Tennessee, Knoxville, TN 37901-1071. analysis. M ore research is needed to hone in on the optimum soybean oil spray rates under alternative environmental and management conditions.

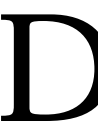

ormant sprays of petroleum oil are currently used on peach trees to kill overwintering insect pests. R esearch at the U niversity of T ennessee has shown that dormant sprays of soybean oil kill overwintering insects and, when applied in water at rates of $8 \%$ to $10 \%$ oil solution, have the added benefits of thinning flower buds and delaying flower bud development by asmuch as $6 \mathrm{~d}$ (D eyton and Sams, 1996). The bud-thinning and bloom-delay effects could reduce peach crop loss resulting from late spring freezes and reduce the cost of thinning flower buds. Furthermore, gaining Environmental Protection Agency (EPA) approval for these uses may be relatively quick and inexpensive because soybean oil is a food product and because of an EPA ruling, which exempts it from normal Federal Insecticide, Fungicide, and RodenticideAct requirements (U .S. C ongress, 1996). The objective of this study was to estimate the potential impacts of the bloom-delay and bud-thinning effects of soybean oil spray on the incomeand risk of peach production.

\section{Materials and methods}

To enable comparison of soybean oil spray with current production technologies, three sets of peach enterprise budgetswere developed for the 198096 period. The first set of enterprise budgets (current-practice budgets) reflected the cost and return of producing peaches in Tennessee using dormant applications of petroleum oil to control scaleinsects such as San J ose scale (Quadraspidi otus perniciosus Comstock) and terrapin scale ( M esolecanium nigrofasciatum Pergandei), and mites such as European red mite (Panonychusulmi Koch). The second set of budgets (bloomdelay budgets) included the bloomdelay effect and was constructed by substituting soybean oil spray for the dormant application of petroleum oil. Based on previous research by $D$ eyton and Sams (unpublished data), soybean oil was emulsified with $10 \%$ lecithin. The soybean oil spray emulsion was applied at an $8 \%$ concentration with water at a rate of $200 \mathrm{gal} /$ acre (1,871 
$\left.\mathrm{L} \cdot \mathrm{ha}^{-1}\right)$. At this concentration, $16 \mathrm{gal} /$ acre $\left(150 \mathrm{~L} \cdot \mathrm{ha}^{-1}\right)$ of soybean oil spray would be applied. In addition to the bloom-delay effect, the third set of budgets (thinning budgets) included the bud-thinning effect of soybean oil spray by reducing the cost of labor for hand thinning by $100 \%, 85 \%$ and $30 \%$

These percentages were chosen because the reduction in hand thinning resulting from soybean oil spray was not know with certainty. Chemical and mechanical thinning have not always been effective in eliminating $100 \%$ of hand-thinning labor. Baugher et al. (1988) found that removal of $45 \%$ to $59 \%$ of blossoms with a mechanical bloom-thinning method reduced hand-thinning labor by $30 \%$; hence, the $30 \%$ thinning budgets were developed asa conservativelower range of reduced hand-thinning labor. The $100 \%$ thinning budgets were developed as an optimistic upper range of reduced labor. These budgets reflect the results of research that found no hand-thinning requirements after using soybean oil spray (D eyton and Sams, 1996), and research that found a commercially acceptable level of chemical thinning, defined as needing no hand thinning (Byers, 1998). The $85 \%$ thinning budgets were developed to account for the possibility that bud thinning may be required in some years to remove double fruits and thin pockets of blossoms that may be unevenly affected by soybean oil spray.

Implicitly assumed in the aforementioned budgets was that peach producers manage the application of soybean oil spray to achieve the desired bloom-delay and thinning effects. In reality, deviations in environmental and management factorscan greatly influence the effectiveness of soybean oil spray in delaying bloom and thinning flower buds. For example, the timing of soybean oil application is important. In fact, applying soybean oil spray before the completion of endodormancy can advance bloom (Erez, 1987; E rez et al., 1971). N evertheless, thisresearch provides insight into the potential benefits of soybean oil spray in a historical setting under ideal environmental and management conditions.

The budgets were based on a mature-orchard peach budget developed by the U niversity of Tennessee Agricultural Extension Servicein 1992 (Johnson and J enkins, 1992). Someof the chemical inputs used in the 1992 peach budget were not in use in the early years of the analysis period. Budgets for all years were based on the 1992 chemical use strategy and peach yield was held constant at the level reported in the 1992 budget except when freeze damage or other known events reduced yields. Consequently, these budgets isolated the economic impacts of soybean oil spray use by eliminating the effects of technological innovation and other factors that would affect production cost and return.

Retail prices of soybean oil spray were not available because no market existed for its use. Consequently, the retail price of dormant soybean oil spray was estimated for Sept. 1998 based on information obtained from Archer D anielsM idland (personal communication). Thepricesfor degummed soybean oil and refined lecithin were $\$ 0.29$ and $\$ 0.52 / \mathrm{lb}$ ( $\$ 0.64$ and $\$ 1.15 / \mathrm{kg})$, respectively. At $7.67 \mathrm{lb} /$ gal $\left(0.92 \mathrm{~kg} \cdot \mathrm{L}^{-1}\right)$ of soybean oil and $8.4 \mathrm{lb} / \mathrm{gal}\left(1.01 \mathrm{~kg} \cdot \mathrm{L}^{-1}\right)$ of lecithin, a dormant soybean oil spray emulsion containing $10 \%$ lecithin was estimated to cost $\$ 2.44 / \mathrm{gal}(\$ 0.64 / \mathrm{L})$. Thecost of putting the emulsion in 55-gal (208 $L$ ) drums for shipment to retailers was estimated to be $\$ 0.46 / \mathrm{gal}(\$ 0.12 / \mathrm{L})$, giving a total material cost of $\$ 2.90$ / gal $(\$ 0.77 / \mathrm{L})$. Applying a 20\%markup for additional manufacturing costsand profit gavean estimated wholesaleprice of $\$ 3.48 /$ gal $(\$ 0.92 / L)$. Finally, a shipping cost of $\$ 0.25 /$ gal $(\$ 0.07 / \mathrm{L})$ (T ennesseeF armers' Cooperative, personal communication) and a $20 \%$ markup to cover other costs and profit gave an estimated retail price of $\$ 4.48$ / gal $(\$ 1.18 / L)$ of dormant soybean oil spray.

Peach prices used for each year of the analysis were state-average nominal prices received by growers as reported annually by the Tennessee Agricultural Statistics Service(T ennessee $\mathrm{D}$ epartment of Agriculture, $\mathrm{N}$ ashville, Tenn.) deflated by the gross domestic product chain price index, $1992=100$ (GDP index) (C ouncil of Economic Advisors, 1998; U .S. Department of Commerce, 1998). Deflated state-average priceswere used to capture the year-to-year interaction of supply and demand on price in Tennessee while eliminating changes in price caused by inflationary pressures. The dormant soybean oil spray price was adjusted to 1992 dollarsusing the GDP index. Other input prices from the 1992 budget were used directly in each annual budget (Johnson and J enkins, 1992). T otal variable costs in 1992 dollarswerethen subtracted from total revenues in 1992 dollars to get returns to land, trees, and ownership (management and risk) for each year. To correspond with the last year of the analysis period, returns were adjusted to constant 1996 dollars using the 1996 value of the GDP index.

$\mathrm{H}$ istorical data for the period 1980-96 from the U niversity of Tennessee'sK noxvilleE xperiment Station (KES) and for 1987-96 from the $M$ iddleT ennessee Experiment Station (MTES) in Spring H ill, were examined to identify years in which the peach crop was lost or reduced because of late spring freezes. In the identified years, peach yields were reduced in the current-practice budgets below the levels expected from a full crop to reflect diminished yields resulting from lost production. Production costs also were adjusted to reflect reduced costs resulting from lost or reduced yields.

To estimate the effectiveness of soybean-oil-induced bloom delay in preventing crop loss, thehistorical data were examined to determine the full bloom datesand thespring freezedates for each year in which there was a crop loss. For some years, there was no full bloom date because the buds were killed by severe winter freezes. For other years in which there was crop lossfrom latespring freezes, thebloomdelay effect from using soybean oil spray was estimated by delaying the historical full bloom dates by 6 calendar days (D eyton and Sams, 1996). The delayed dates for each stage of bloom, which included all bloom stages from first swelling to post bloom, then were estimated based on growing degree hour requirements as described by Logan et al. (1990).

The delayed bloom periods for the years in which the experiment station data indicated a crop loss were compared to daily minimum temperature datafrom each experiment station to determine if a damaging freeze occurred during the delayed bloom period. If a daily minimum temperature fell below the critical temperature for $90 \%$ bud mortality during a particular bloom stage, budgeted peach yield was reduced to zero. The critical tem- 
T able 1. T ennessee peach enterprise budget for 1980 with current production practices, mature orchard, 110 trees/acre, 1992 dollars.

\begin{tabular}{|c|c|c|c|c|c|}
\hline Item & Description & U nit & Q uantity & Price (\$) & Amount (\$) \\
\hline Peaches & 2 Bushel/ tree & bushel $^{z}$ & 220 & 14.75 & $3,244.95$ \\
\hline Fertilizer & $10 \mathrm{~N}-4.3 \mathrm{P}-8.3 \mathrm{~K}$ & $\mathrm{lb}(0.454 \mathrm{~kg})$ & 330 & 0.06 & 19.80 \\
\hline Lime & & ton $(0.907 \mathrm{t})$ & 0.4 & 14.00 & 5.60 \\
\hline D ormant oil-petroleum & & gal (3.785 L) & 4.5 & 2.59 & 11.66 \\
\hline H erbicide & Paraquat & qt $(0.947 \mathrm{~L})$ & 1.25 & 8.40 & 10.50 \\
\hline Fungicide & Captan & $\mathrm{lb}$ & 2 & 2.63 & 5.26 \\
\hline Fungicide & Benomyl & $\mathrm{Ib}$ & 0.5 & 15.25 & 7.63 \\
\hline Insecticide & Azinphosmethyl & $\mathrm{lb}$ & 9 & 5.11 & 45.99 \\
\hline Insecticide & Formetenate & oz $(0.03 \mathrm{~L})$ & 10 & 0.90 & 9.00 \\
\hline $\mathrm{H}$ and thinning & & $\mathrm{h}$ & 30 & 5.25 & 157.50 \\
\hline Trunk spray & Chlorpyrifos & qt & 1.5 & 11.15 & 16.73 \\
\hline Baskets & 1/ 2 bushel & each & 440 & 1.00 & 440.00 \\
\hline \multicolumn{6}{|c|}{ Return to land, trees, and ownership } \\
\hline 1992 dollars & & acre & & & $2,255.88$ \\
\hline 1996 dollars & & acre & & & $2,471.09$ \\
\hline
\end{tabular}

z1 bushel $=50 \mathrm{lb}(22.6 \mathrm{~kg})$.

peratures used in the model were 1.0, $5.0,9.0,15.0,21.0,24.0$, and $25.0^{\circ} \mathrm{F}$ $(-17.2,-15.0,-13.8,-9.4,-6.1,-$ 4.4 , and $-3.9{ }^{\circ} \mathrm{C}$ ) for first swelling, green calyx, red calyx, first pink, first bloom, full bloom, and post bloom, respectively (Griffin, 1984). For cases in which the minimum temperature was equal to the critical temperature, budgeted peach yields were reduced by $50 \%$ to reflect $10 \%$ bud survival. If the minimum temperatures did not reach the critical temperatures during the delayed bloom period, yields for a full peach crop were budgeted indicating $100 \%$ bud survival.

Peach yields in the bloom-delay budgets were revised to represent increased production in years in which bloom delay was estimated to be effective in reducing losses from late spring freezes. For this portion of the analysis, the cost of hand thinning was retained in the budgets to isolate the income effects of bloom delay.

Peach yields in the thinning budgets used the same yield each year as estimated for the bloom-delay budgets. Theincomeeffects of $100 \%, 85 \%$, and $30 \%$ reductions in the cost of hand thinning were incorporated into these budgets for each year in which hand thinning would otherwise have been required. For some years of the analysis, hand thinning would not have been required because of bud mortal- ity from freeze damage.

One reason peach producers might want to use soybean oil spray is if it reduces risk. Risk is defined by economists as variation in income caused by factors outside the farmer's control (Boehlje and Eidman, 1984).

In this research, risk is represented by the variance in income caused by changes in peach yield per acre and changes in cost resulting from using either petroleum or soybean oil spray, with peach pricesand other input prices

held constant among alternatives. If a particular production alternative has an average annual income (expected income) greater than or equal to another alternative and a lower variance in income, it is unambiguously less risky than the other alternative. If the mean and variance of income are both higher or both lower for one alternative than another, an unambiguous statement about the risk of one alternativeversustheother cannot bemade. $\mathrm{H}$ owever, the relative risk of the two

Table 2. Peach full bloom dates, freeze kill dates, and budgeted peach yields for the current-practice budgets, K noxville E xperiment Station, 1980-96.

\begin{tabular}{lccr}
\hline Year & $\begin{array}{c}\text { Full bloom } \\
\text { date }\end{array}$ & $\begin{array}{c}\text { F reeze } \\
\text { date }\end{array}$ & $\begin{array}{c}\text { Budgeted yield } \\
\text { (bushels/acre) }\end{array}$ \\
\hline 1980 & 3 April & No freeze damage & 220 \\
1981 & 1 April & No freeze damage & 220 \\
1982 & $22 \mathrm{M}$ arch & 7 April & 0 \\
1983 & $25 \mathrm{M}$ arch & 19 April & 0 \\
1984 & $1 \mathrm{April}$ & No freeze damage & 220 \\
1985 & N o full bloom & 21 J anuary & 0 \\
1986 & $26 \mathrm{M}$ arch & No freeze damage & 220 \\
1987 & $30 \mathrm{M}$ arch & 1 April & 110 \\
1988 & $28 \mathrm{M}$ arch & No freeze damage & 220 \\
1989 & $17 \mathrm{M}$ arch & No freeze damage & 110 \\
1990 & $15 \mathrm{M}$ arch & 21 M arch & 0 \\
1991 & $23 \mathrm{M}$ arch & No freeze damage & 220 \\
1992 & $22 \mathrm{M}$ arch & 3 A pril & 0 \\
1993 & $5 \mathrm{April}$ & No freeze damage & 220 \\
1994 & $25 \mathrm{M}$ arch & No freeze damage & 220 \\
1995 & $28 \mathrm{M}$ arch & No freeze damage & 220 \\
1996 & N full bloom & 5 February & 0 \\
\hline
\end{tabular}

z1 bushel/ acre $=50 \mathrm{lb} /$ acre $\left(56 \mathrm{~kg} \cdot \mathrm{ha}^{-1}\right)$. 
T able 3. E stimated delayed bloom dates, damaging freeze dates, and budgeted peach yields for years when bloom delay could have been effective in reducing crop losses, Knoxville Experiment Station, K noxville, Tenn.

\begin{tabular}{cccc}
\hline Year & $\begin{array}{c}\text { Delayed full } \\
\text { bloom date }\end{array}$ & $\begin{array}{c}\text { Damaging } \\
\text { freeze date }\end{array}$ & $\begin{array}{c}\text { Budgeted yield } \\
\text { (bushels/acre) }\end{array}$ \\
\hline 1982 & $28 \mathrm{March}$ & $7 \mathrm{April}$ & 0 \\
1983 & $31 \mathrm{M}$ arch & $19 \mathrm{April}$ & 0 \\
1987 & $5 \mathrm{April}$ & No freeze damage & $220^{\mathrm{y}}$ \\
1990 & $21 \mathrm{M}$ arch & $21 \mathrm{M}$ arch & $110^{\mathrm{y}}$ \\
1992 & $28 \mathrm{M}$ arch & $3 \mathrm{April}$ & 0
\end{tabular}

z1 bushel/ acre $=50 \mathrm{lb} /$ acre $\left(56 \mathrm{~kg} \cdot \mathrm{ha}^{-1}\right)$.

yYieldswere budgeted to increase by 110 bushels/ acrefrom theyieldsin T able 2 asa result of using soybean oil spray. This 110-bushel increase represents half of a full crop.

alternatives can be inferred. Relative risk can be measured by comparing the coefficients of variation of the two alternatives. If a particular alternative has a lower variance (or standard deviation) in income, compared to its average annual income, than another alternative, it is relatively less risky. Thus, one alternative is relatively less risky than another alternative if its coefficient of variation is smaller. With regard to this study, the hypothesis is that using soybean oil for bloom delay and fruit thinning is less risky than not using it. The means, standard deviations, and coefficients of variation of returns to land, trees, and ownership are calculated for the current-practice and thinning budgets to test this hypothesis.

\section{Results and discussion}

Table 1 shows an example of a current-practicebudget for ayear without freeze damage (1980) expressed in 1992 dollars. The budgeted peach yield of 220 bushels/ acre $(12,320$ $\left.\mathrm{kg} \cdot \mathrm{ha}^{-1}\right)$ and the 1980 peach price of $\$ 14.75 /$ bushel $(\$ 0.64 / \mathrm{kg}$ ) (in 1992 dollars) resulted in gross revenue of $\$ 3,245 /$ acre $(\$ 8,019 /$ ha) [ 1 bushel $=$ $50 \mathrm{lb}(22.6 \mathrm{~kg})]$. T otal variable production expenses were $\$ 989 /$ acre $(\$ 2,444 / \mathrm{ha})$ which resulted in a return to land, trees, and ownership of $\$ 2,256 /$ acre $(\$ 5,575 / \mathrm{ha})$ in 1992 dollars and $\$ 2,471 /$ acre $(\$ 6,106 /$ ha $)$ in 1996 dollars.

For the 1980 bloom-delay budget (not shown), variable production expenses were $\$ 1,041 /$ acre $(\$ 2,572$ / ha). These expenses were $\$ 52 /$ acre (\$128/ ha) higher than the variable expenses for the current-practice budget because of the higher cost of soybean oil spray compared to petroleum oil spray. When reduced labor requirements were included in the 1980 thin- ning budget for hand-thinning labor savings of $100 \%$ (not shown), total variable expenses were $\$ 884 /$ acre $(\$ 2,184 / \mathrm{ha})$, which was $\$ 105 /$ acre ( $\$ 259 / \mathrm{ha}$ ) less than the current-practice budget. As a result, returns to land, trees, and ownership were $\$ 2,204$ and $\$ 2,361 /$ acre $(\$ 5,446$ and $\$ 5,834 /$ ha) in 1992 dollars and $\$ 2,415$ and $\$ 2,587 /$ acre $(\$ 5,968$ and $\$ 6,393 /$ ha) in 1996 dollars for the bloomdelay and $100 \%$ thinning budgets, respectively.

The last column of Table 2 shows the peach yields used in the currentpractice budgets for KES during the
1980-96 period. During that period, the peach crop was destroyed by late spring freezes in 1982, 1983, 1990, and 1992, and by severe winter freezes in 1985 and 1996. A spring freeze in 1987 resulted in yield being reduced to half of the full budgeted yield. In 1989 , yield was reduced by factors other than freeze damage.

The last column of Table 3 presents the yields budgeted for the bloom-delay and thinning budgets for years when boom delay could have been effective. Yields in these budgets for other years were the same as those reported in Table 2 for the currentpractice budgets. For 1982, 1983, and 1992, estimatesfor KES indicated that delayed bloom would not have saved the crop. Estimates indicated that delayed bloom would have saved the entire crop in 1987, increasing budgeted yield from 110 to 220 bushels/ acre $\left(6,225\right.$ and $\left.12,449 \mathrm{~kg} \cdot \mathrm{ha}^{-1}\right)$. In 1990, a minimum temperature equal to the critical temperature for $90 \%$ bud kill occurred on the same day as the estimated delayed full bloom date; therefore, $10 \%$ bud survival increased budgeted yield from 0 to 110 bushels/ acre $\left(0\right.$ to $\left.6,225 \mathrm{~kg} \cdot \mathrm{ha}^{-1}\right)$.

Table 4. R edhaven peach full bloom dates, freeze kill dates, and budgeted peach yields, Middle T ennessee Experiment Station, Spring H ill, T enn., 1987-97.

\begin{tabular}{lccr}
\hline Year & $\begin{array}{c}\text { Full bloom } \\
\text { date }\end{array}$ & $\begin{array}{c}\text { F reeze } \\
\text { date }\end{array}$ & $\begin{array}{r}\text { Budgeted yield } \\
\text { (bushels/acre) }\end{array}$ \\
\hline 1987 & $1 \mathrm{April}$ & 1 April & 0 \\
1988 & $28 \mathrm{M}$ arch & N o freeze damage & 220 \\
1989 & $22 \mathrm{M}$ arch & 11 A pril & 0 \\
1990 & $16 \mathrm{M}$ arch & 8 April & 0 \\
1991 & $25 \mathrm{M}$ arch & N o freeze damage & 220 \\
1992 & $26 \mathrm{M}$ arch & 3 April & 0 \\
1993 & $12 \mathrm{April}$ & N o freeze damage & 220 \\
1994 & $1 \mathrm{April}$ & N o freeze damage & 110 \\
1995 & $31 \mathrm{M}$ arch & N o freeze damage & 220 \\
1996 & N o full bloom & 4 February & 0
\end{tabular}

${ }^{2} 1$ bushel/ acre $=50 \mathrm{lb} /$ acre $\left(56 \mathrm{~kg} \cdot \mathrm{ha}^{-1}\right)$.

Table 5. Estimated delayed bloom dates, damaging freeze dates, and budgeted peach yields for years when bloom delay could have been effective in reducing crop losses, Middle Tennessee Experiment Station, Spring H ill, Tenn.

\begin{tabular}{lccc}
\hline Year & $\begin{array}{c}\text { Delayed full } \\
\text { bloom date }\end{array}$ & $\begin{array}{c}\text { Damaging } \\
\text { freeze date }\end{array}$ & $\begin{array}{c}\text { Budgeted yield } \\
\text { (bushels/acre) }\end{array}$ \\
\hline 1987 & $7 \mathrm{April}$ & $1 \mathrm{April}$ & $110^{\mathbf{y}}$ \\
1989 & $28 \mathrm{M}$ arch & $11 \mathrm{April}$ & 0 \\
1990 & $22 \mathrm{M}$ arch & $8 \mathrm{April}$ & 0 \\
1992 & $1 \mathrm{April}$ & $3 \mathrm{April}$ & 0
\end{tabular}

z1 bushel/ acre $=50 \mathrm{lb} /$ acre $\left(56 \mathrm{~kg} \cdot \mathrm{ha}^{-1}\right)$.

yield was budgeted to increase by 110 bushels/ acre from the yield in Table 4 as a result of using soybean oil spray. This 110-bushel increase represents half of a full crop. 
T able 6. Per acre returns with and without bloom delay, Knoxville Experiment Station (KES) and Middle Tennessee Experiment Station (MTE S), 1996 constant dollars.

\begin{tabular}{|c|c|c|c|c|}
\hline Year & $\begin{array}{c}\text { Returns without } \\
\text { bloom delay } \\
\text { and bud thinning, } \\
\text { KES } \\
\text { (current practice) }\end{array}$ & $\begin{array}{c}\text { Returns with } \\
\text { bloom delay, } \\
\text { KES } \\
\text { (bloom delay) }\end{array}$ & $\begin{array}{c}\text { Returns without } \\
\text { bloom delay } \\
\text { and bud thinning, } \\
\text { MTES } \\
\text { (current practice) }\end{array}$ & $\begin{array}{c}\text { Returns with } \\
\text { bloom delay, } \\
\text { MT ES } \\
\text { (bloom delay) }\end{array}$ \\
\hline & \multicolumn{4}{|c|}{$\$ /$ acre $^{2}$} \\
\hline 1980 & 2,471 & 2,415 & --- & --- \\
\hline 1981 & 2,294 & 2,237 & --- & --- \\
\hline 1982 & -272 & -329 & -- & --- \\
\hline 1983 & -272 & -329 & --- & --- \\
\hline 1984 & 2,250 & 2,193 & -- & --- \\
\hline 1985 & -272 & -329 & -- & -- \\
\hline 1986 & 2,505 & 2,449 & -- & --- \\
\hline 1987 & 1,912 & 3,880 & -272 & 1,855 \\
\hline 1988 & 3,073 & 3,017 & 3,073 & 3,017 \\
\hline 1989 & 1,880 & 1,824 & -272 & -329 \\
\hline 1990 & -272 & 1,726 & -272 & -329 \\
\hline 1991 & 2,631 & 2,575 & 2,631 & 2,575 \\
\hline 1992 & -272 & -329 & -272 & -329 \\
\hline 1993 & 3,378 & 3,322 & 3,378 & 3,322 \\
\hline 1994 & 3,549 & 3,493 & 1,718 & 1,661 \\
\hline 1995 & 2,884 & 2,828 & 2,884 & 2,828 \\
\hline 1996 & -272 & -329 & -272 & -329 \\
\hline M ean return & 1,600 & 1,783 & 1,233 & 1,394 \\
\hline Additional mean return & --- & 183 & --- & 161 \\
\hline
\end{tabular}

Yields used in the current-practice budgets for MTES during the 1987-96 period are shown in the last column of Table 4. Peach crops were destroyed by latespring freezesin 1987 , 1989,1990 , and 1992. In 1994, the crop was reduced by factors other than freeze damage. In 1996, the crop was destroyed by a severe winter freeze.

The last column of Table 5 presents the yields used in the bloomdelay and thinning budgetsfor M TES

T able 7. Per acre returns with and without bloom delay and $100 \%, 85 \%$, and $30 \%$ savings of bud-thinning labor, Knoxville Experiment Station, Knoxville, Tenn., 1996 constant dollars.

\begin{tabular}{|c|c|c|c|c|}
\hline Year & $\begin{array}{l}\text { Returns without } \\
\text { bloom delay } \\
\text { and bud thinning } \\
\text { (current practice) }\end{array}$ & $\begin{array}{l}\text { Returns with } \\
\text { bloom delay } \\
\text { and bud thinning } \\
\text { (100\% thinning) }\end{array}$ & $\begin{array}{l}\text { Returns with } \\
\text { bloom delay } \\
\text { and bud thinning } \\
\text { ( } 85 \% \text { thinning) }\end{array}$ & $\begin{array}{l}\text { Returns without } \\
\text { bloom delay } \\
\text { and bud thinning } \\
\text { (30\% thinning) }\end{array}$ \\
\hline & \multicolumn{4}{|c|}{$\$ /$ acre $^{2}$} \\
\hline 1980 & 2,471 & 2,587 & 2,562 & 2,467 \\
\hline 1981 & 2,294 & 2,410 & 2,384 & 2,289 \\
\hline 1982 & -272 & -329 & -329 & -329 \\
\hline 1983 & -272 & -329 & -329 & -329 \\
\hline 1984 & 2,250 & 2,366 & 2,340 & 2,245 \\
\hline 1985 & -272 & -329 & -329 & -329 \\
\hline 1986 & 2,505 & 2,622 & 2,596 & 2,501 \\
\hline 1987 & 1,912 & 4,053 & 4,027 & 3,932 \\
\hline 1988 & 3,073 & 3,189 & 3,164 & 3,069 \\
\hline 1989 & 1,880 & 1,824 & 1,824 & 1,824 \\
\hline 1990 & -272 & 1,726 & 1,726 & 1,726 \\
\hline 1991 & 2,631 & 2,747 & 2,722 & 2,627 \\
\hline 1992 & -272 & -329 & -329 & -329 \\
\hline 1993 & 3,378 & 3,494 & 3,469 & 3,374 \\
\hline 1994 & 3,549 & 3,665 & 3,640 & 3,545 \\
\hline 1995 & 2,884 & 3,000 & 2,975 & 2,880 \\
\hline 1996 & -272 & -329 & -329 & -329 \\
\hline M ean return & 1,600 & 1,885 & 1,870 & 1,814 \\
\hline SD & 1,445 & 1,538 & 1,527 & 1,487 \\
\hline $\mathrm{cV}$ & 90 & 82 & 82 & 82 \\
\hline Additional mean return & --- & 285 & 271 & 217 \\
\hline
\end{tabular}


T able 8. Per acre returns with and without bloom delay and $100 \%, 85 \%$, and $30 \%$ savings of bud-thinning labor, Middle Tennessee Experiment Stations, Spring H ill, Tenn., 1996 constant dollars.

\begin{tabular}{|c|c|c|c|c|}
\hline Year & $\begin{array}{l}\text { R eturns without } \\
\text { bloom delay } \\
\text { and bud thinning } \\
\text { (current practice) }\end{array}$ & $\begin{array}{l}\text { Returns with } \\
\text { bloom delay } \\
\text { and bud thinning } \\
\text { (100\% thinning) }\end{array}$ & $\begin{array}{c}\text { Returns with } \\
\text { bloom delay } \\
\text { and bud thinning } \\
\text { (85\% thinning) }\end{array}$ & $\begin{array}{l}\text { Returns without } \\
\text { bloom delay } \\
\text { and bud thinning } \\
\text { (30\% thinning) }\end{array}$ \\
\hline & \multicolumn{4}{|c|}{$\$ /$ acre $^{2}$} \\
\hline 1987 & -272 & 1,855 & 1,855 & 1,855 \\
\hline 1988 & 3,073 & 3,189 & 3,164 & 3,069 \\
\hline 1989 & -272 & -329 & -329 & -329 \\
\hline 1990 & -272 & -329 & -329 & -329 \\
\hline 1991 & 2,631 & 2,747 & 2,722 & 2,627 \\
\hline 1992 & -272 & -329 & -329 & -329 \\
\hline 1993 & 3,378 & 3,494 & 3,469 & 3,374 \\
\hline 1994 & 1,718 & 1,661 & 1,661 & 1,661 \\
\hline 1995 & 2,884 & 3,000 & 2,975 & 2,880 \\
\hline 1996 & -272 & -329 & -329 & -329 \\
\hline M ean return & 1,233 & 1,463 & 1,453 & 1,415 \\
\hline SD & 1,556 & 1,554 & 1,544 & 1,504 \\
\hline CV & 126 & 106 & 106 & 106 \\
\hline Additional mean return & -- & 230 & 220 & 183 \\
\hline
\end{tabular}

z $\$ 1 /$ acre $=\$ 2.47 /$ ha.

for years when bloom delay could have been effective. Yields in these budgets for other years were the same as those reported in Table 4 for the currentpractice budgets. In 1987, the temperature dropped to the critical temperature for $90 \%$ bud kill when the buds were estimated to be in the firstbloom stage on 1 A pril. For that year, $10 \%$ bud survival increased budgeted yield from 0 to 110 bushels/ acre (0 to $\left.6,225 \mathrm{~kg} \cdot \mathrm{ha}^{-1}\right)$. For theremaining years, temperatures below the $90 \%$ bud kill temperature occurred after the delayed full bloom dates and bloom delay was insufficient to save the crops.

Because soybean oil spray was more costly than petroleum oil spray, returns in 1996 dollars were lower for the bloom-delay budgets than for the current-practicebudgetsin yearswhen soybean oil spray was not effective in influencing yields (T able 6). I n fact, at KES, returns were lower with bloom delay than without it in 15 of 17 years. In only 2 of 17 years (1987 and 1990) were returns higher with bloom delay than without it. N evertheless, returns were sufficiently higher in those two years to increase average annual returns enough to make the use of soybean oil spray for bloom delay $\$ 183$ / acre ( $\$ 452 / \mathrm{ha})$ more profitable than without bloom delay. Similarly, at MTES, bloom delay was effective in only one of 10 years, but the higher return in that year offset the lower returns in the other 9 years enough to make the annual use of soybean oil spray for bloom delay $\$ 161 /$ acre
$(\$ 398 / \mathrm{ha})$ more profitablethan without it.

When the additional production cost savings resulting from the budthinning effect of soybean oil spray were included at $100 \%$ and $85 \%$, returns were higher with soybean oil spray than without it in 11 of 17 years at the KES (Table 7). In the other six years when returns were lower with soybean oil spray $(1882,1983,1985$, 1989,1992 , and 1996), soybean oil spray was not effective in saving the entire peach crop so there was no cost savings from reduced hand thinning labor. The 30\%thinning budgets had lower returns in all years except 1987 and 1990 when partial peach crops were saved by bloom delay. When bud-thinning effects were included along with thebloom delay effects, the increases in average annual returns compared to current production practices were estimated to be $\$ 285 /$ acre (\$704/ ha), \$271/ acre (\$669/ ha), and $\$ 217 /$ acre $(\$ 536 /$ ha) for the $100 \%, 85 \%$ and $30 \%$ thinning budgets, respectively. Also, compared to bloom-delay budgets, the $100 \%, 85 \%$, and $30 \%$ thinning budgets respectively provided \$102/ acre (\$252/ ha), \$88/ acre ( $\$ 217 / \mathrm{ha})$, and $\$ 34 /$ acre ( $\$ 84 /$ ha) higher average annual returns at KES.

At M TES (Table 8), average annual returns were higher compared to the current-practices budgets in 5 of 10 years when the benefits of bud thinning were included in the $100 \%$ and $85 \%$ thinning budgets. Aswith the
$30 \%$ thinning budgets for KES, the return washigher only in 1987 when a partial crop was saved by bloom delay. The increases in average annual net returns compared to the current-practice budget were $\$ 230 /$ acre $(\$ 568 /$ ha), $\$ 220 /$ acre ( $\$ 543 / \mathrm{ha})$, and $\$ 183 /$ acre $(\$ 452 / \mathrm{ha})$ for the $100 \%, 85 \%$ and $30 \%$ thinning budgets, respectively. Furthermore, compared to bloom-delay budgets, the $100 \%, 85 \%$, and $30 \%$ thinning budgetsrespectively provided higher average annual returns of $\$ 69 /$ acre ( $\$ 170 / \mathrm{ha}), \$ 59 /$ acre ( $\$ 146 / \mathrm{ha})$, and $\$ 22 /$ acre $(\$ 54 /$ ha) at MTES.

Tables 7 and 8 present the standard deviationsand coefficients of variation of returnsfor the current-practice and thinning budgets. For KES (T able 7), mean returns were higher with soybean oil spray, but standard deviationswerealso higher leaving no clearly superior alternative in terms of the tradeoff between expected return and variance of returns. $\mathrm{N}$ evertheless, the lower coefficients of variation suggest that using soybean oil spray to delay bloom and thin fruit was less risky relative to mean returns than current production practices regardless of whether labor savingswere $100 \%, 85 \%$, or $30 \%$ For MTES (Table 8 ), the soybean oil spray alternatives also had lower coefficients of variation than using current practices. In addition, the standards deviations of returns decreased slightly, suggesting that soybean oil spray unambiguously reduced economic risk at that location. 


\section{Conclusions}

The estimated annual cost of dormant soybean oil spray applications to delay bloom, thin fruit, and control mites and scale insects was higher than the cost of using petroleum oil spray applicationsto control mites and scale insects al one. This higher annual cost, however, was more than offset by higher average annual revenues resulting from the reduction in crop losses caused by thebloom-delaying effect of soybean oil spray. Substantial economic benefits were estimated from using soybean oil spray to delay bloom and thin fruit even when only half a peach crop wassaved twice in 17 years ( $1980-$ $96)$ at KES and oncein 10 years (198796) at the M TES.

Results also suggest that relative risk could be reduced at both location by using soybean oil spray to delay bloom and thin fruit rather than current practices. In addition, at M TES, soybean oil spray would unambiguously reduce risk.

If all peach producers used soybean oil spray to delay bloom and the crop were saved in a given year, peach supply would have been higher than its historical level and the peach price in that year likely would have been lower than the historical price used in this study. Thus, return to land, trees, and ownership would havebeen lower than estimated in thebloom-delay and thinning budgets. Nevertheless, the results of thisstudy would hold for early adopters of soybean oil spray until sufficiently large numbers of adopters began to have an appreciable effect on supply.
A simplifying assumption was made that peach producers efficiently manage the use of soybean oil spray to achievetheoptimum bloom-delay and fruit-thinning results. Although the soybean oil spray rates in this study were shown to be effective in T ennessee experiments, their effectiveness is sensitive to differences from year to year in environmental conditions. Furthermore, mismanagement of soybean oil spray could add to cost without delaying bloom or thinning fruit or, at the other extreme, over-thin the fruit or advance bloom causing economic loss from underproduction and increased possibility of freeze damage. Risk resulting from unanticipated environmental conditions and mismanagement were not considered in this analysis. Knowing how unanticipated environmental conditionsand mismanagement influence the effectiveness of soybean oil spray in optimally delaying bloom and thinning fruit is important before strongly recommending soybean oil spray for these uses. $M$ ore research is needed to hone in on the optimum soybean oil spray rates under alternative environmental and management conditions.

\section{Literature cited}

Baugher, T.A., K.C. Elliot, S.H . Blizzard, S.I. Walter, and T.A. Keiser. 1988. Mechanical bloom thinning of peach. $\mathrm{H}$ ortScience 23:981-983.

Boehlje, M.D. and V.R. Eidman. 1984. Farm management. Wiley, N ew York.

Byers, R.E. 1988. Peach bloom thinning with dessicating chemicals, p. 662-663. In: N .F. Childersand W.B. Sherman (eds.).
The peach. H orticultural Publ., Gainesville, Fla.

Council of Economic Advisors. 1998. Economic report of the president. U .S. Govt. Printing O ffice, Washington, D.C.

Deyton, D.E. and C.E. Sams. 1996. Applying soybean oil to dormant peach trees al tersinternal atmosphere, reducesrespiration, delays bloom, and thins flower buds. J. Amer. Soc. H ort. Sci. 121:96-100.

Erez, A. 1987. Chemical control of budbreak. H ortScience 22:1240-1243.

Erez, A., S. Lavee, and R.M. Samish. 1971. I mproved methods for breaking rest in the peach and other deciduo us fruit species. J . Amer. Soc. H ort. Sci. 96:519-522.

Griffin, R.E. 1984. M icro-climate control in deciduous orchards by use of overhead sprinklers to delay bloom-To protect against late spring freezes and for color enhancement. Four Corners Reg. Commission Project 652-366-084, U tah State U niv., Logan.

Johnson, L.A. and R.P. Jenkins. 1992. Fruit and vegetable planning guide. U niv. Tenn. Agr. Ext. Serv. Publ. EC 890.

Logan, J., D.E. Deyton, and D.W. L ockwood. 1990. U sing achill unit/ growing degree hour model to assess spring freeze risks for 'Redhaven' peach trees. H ortScience 25:1382-1384.

U.S. C ongress. 1996. Exemption of certain pesticide substances from federal insecticide, fungicide, and rodenticide act requirements. Federal registry (40 CFR Part 152). U.S. Government Printing Office, Washington, D.C., $6 \mathrm{M}$ ar. 1996.

U.S. D epartment of Commerce. 1998. Bureau of economic analysis news release, 25 Aug. 1998. Accessed 18 Sept. 1998. <www.bea.doc.gov/ bea/ newsrel/ gdp298f.htm.> 